\title{
Indian Butter Tree: A Panacea for Many Ailments
}

\author{
Sadhu Charan Panda* \\ PG Department of Community Medicine, VSS Institute of Medical Sciences \& Research, India
}

Submission: September 22, 2018; Published: October 26, 2018

*Corresponding author: Professor \& Head,PG Department of Community Medicine and Registrar,VSS Institute of Medical Sciences \& Research, Burla, Sambalpur-768017, Odisha, India; Email ID: scpanda@vimsar.ac.in

Keywords: Herbal medicine; Ailments; Drugs; Quality; Rich heritage; Tremendous therapeutic potential; Economic plant growing; Madhuca Longifolia

\section{Introduction}

Use of herbal medicine for cure of ailments is a tradition from time immemorial and still it is practiced among the community. Tribal community are dependent on forest products and they use different parts of plants for various purposes including medicinal use.In past decades, lot of scientific research and development is focussed on herbalmedicine for treatment of various health challenges in different national healthcare settings. Herbal medicine is used across the Globe in a large scale and very often it is used along with other drugs[1].Among theTraditional medicinepractice most commonly used practice in developing countries isherbal medicine[2].Majority in Africa use herbs in their day to day life to treat ailments[3].

In China, traditional herbal medicine along with western medicine was tried to tackle SARS though the expert committee suggestedto ensureeffectiveness of conventional Chinese medicine based on herbs andmaintain utmost standard and quality [4].

India too has a rich heritage in terms of use of herbs in traditional medicine especially among tribal populations besides the research work embodied in "Charaka Samhita: wherein details of use of medicinal plants are mentioned. India too is not lagging behind in the field of herbal pharmacology.Out of so many medicinal plants available in the flora of India in different terrain mahua plant or MadhucaLongifolia(Indian butter tree) is a plant of Indian origin which is a large to medium deciduous tree of familySapotaceae.It is an important economic plant growing throughout the subtropical region of the Indian subcontinent Tribes uses its different parts as food, drink, construction of house and most important use as a medicine. Itstremendous therapeutic potential needs to be unravelledAdvocacy and awareness among researchers, botanists, biochemists, pharmacologists and biotechnologistshas to be made to utilize all its potential for the benefit of Mankind.
Active constituents present inside the different part of the plant, determine the therapeutic value of the plant including secondary metabolites.Saponin, is an alkaloidfound in the leaves, and. Sapogenin which is aglucosideispresent and seeds of this plant. Various Photochemical studies on this wonder treeascertained the presence steroids, saponin, flavonoids and many active ingredientsincludingnewercomponents likemadhucic acid (penta cyclic triterpenoids), madhushazone, four new oleanane type triterpene glycosides and madhucosides A and Bwhich have medicinal properties[5].

Traditionally its bark has been used against diabetes, rheumatism, ulcers, bleeding and tonsillitis. Its different parts have anti-inflammatory, analgesic and antipyretic properties. Its use has been evidenced against infertility, hyperglycemias, bacterial infections and cancer.Long back, I had prescribed acyclovir for an adult who had herpes with blisters all over his trunk. After few days he came to me and I saw thepatient was asymptomatic. I was happy thinking that the antiviral has worked. But the patient told that he could not purchase the drug because it was costly for him. As per the advice of local traditional healer he took seedcake of MadhucaLongifoliaand burnt it. He exposed his body to the smoke or fumes of the seedcake andall the blisters were fallen. Its antiviral property needs to be confirmed by further research[6].

\section{Conclusion}

The Medicinal properties of this wonderful Mahua tree are not known to the researchers of today. On the backdrop of antimicrobial resistance, lack of affordability of people of developing countries, researchers should show interest and work intensively towards finding different ingredients of this plant and conduct experiment for treating ailments which will benefit Mankind in terms of less cost, minimal side effect and socio-cultural acceptability of herbal medicine by the community. 


\section{References}

1. WHO (2004) WHO Guidelines on Safety Monitoring of Herbal Medicines in Pharmacovigilance Systems. Geneva, Switzerland: World Health Organization.

2. Mukherjee PW (2002)Quality Control of Herbal Drugs: An Approach to Evaluation of BotanicalsBusiness Horizons Publishers, New Delhi, India.

3. Willcox ML, Bodeker G (2004) Traditional herbal medicines for malaria. BMJ 329(7475): 1156-1159.
4. SARS (2003) Clinical trials on treatment using a combination of traditional chinese medicine and western medicine. Geneva: WHO, Switzerland, pp. 53-61.

5. Bina S Siddiqui, Shazia Khan, M Nadeem Kardar (2010) A New Isoflavone from the Madhucalatifolia. Nat Prod Res24(1): 76-80.

6. Patel KP,Narendra K. Prajapati and B.K. Dubey(2012) Madhuca Indica:A Review of Its Medicinal Property. IJPSR3(5): 1285-1293.

\section{Your next submission with Juniper Publishers will reach you the below assets}

- Quality Editorial service

- Swift Peer Review

- Reprints availability

- E-prints Service

- Manuscript Podcast for convenient understanding

- Global attainment for your research

- Manuscript accessibility in different formats

( Pdf, E-pub, Full Text, Audio)

- Unceasing customer service

Track the below URL for one-step submission https://juniperpublishers.com/online-submission.php 